\title{
IMPACT OF USING YEAST AS FEED ADDITIVE ON PRODUCTION PERFORMANCE AND IMMUNE RESPONSES OF SHE-CAMELS AND THEIR NEWBORN CALVES DURING PERI-PARTURATION PERIOD By
}

MAYSOON M. MOHIE EL-DINN ${ }^{1,2^{*}}$, EHAB S. ABDEL-AAL ${ }^{2}$, LAILA N. EID ${ }^{2}$, ALYAA A. FARID ${ }^{1}$, IBRAHIM R. ALY ${ }^{3}$ AND SOMAYA O. EL-DEEB ${ }^{1}$

Department of Zoology, Faculty of Science, Cairo University ${ }^{1}$, Giza, Animal Production Research Institute (APRI), Agricultural Research Center ${ }^{2}$, Dokki, Giza And Theodore Bilharz Research Institute ${ }^{3}$, Embaba P. O. Box 30, Giza, Egypt ( ${ }^{\star}$ Correspondence:mm.arc@hotmail.com)

\begin{abstract}
She-camels face down-regulation of immune responses during pregnancy that may lead to viral and bacterial infections so increases the dangers affecting their newborn calves. This study aimed to improve the body weight and immune responses of she-camels and their newborn calves. A total of 10 dams were divided into two equal groups; $\mathrm{G}_{1}$ (fed the basal diet only) and $\mathrm{G}_{2}$ (fed the basal diet \& Saccharomyces cerevisiae (SC); $0.5 \mathrm{~g} / \mathrm{head} / \mathrm{day}$ ). Dams' and calves' plasma, milk samples were collected. Quantitative analysis of IgG, IgA \& IFN- $\gamma$ levels in samples was done by ELISA and Body weights were recorded monthly. Results revealed significant increases $(\mathrm{P}<0.05)$ in body weight, body weight gain of dams and calves' birth weight in $\mathrm{G}_{2}$ compared to $\mathrm{G}_{1}$. $\mathrm{IgG}_{2}$ levels dams were higher than $\mathrm{IgG}_{1}$ at all durations, $\operatorname{Ig}$ A levels didn't show any significant change in groups while IFN- $\gamma$ showed an increased level in $G_{2}$ more than $G_{1}$ from the time of calving to one month post calving. IgG, IgA \& IFN- $\gamma$ levels in milk didn't show significant differences between the experimental groups. Calves' IgG in $G_{2}$ showed higher significant levels compared to $\mathrm{G}_{1}$ from birth to one month after birth, IgA \& IFN- $\gamma$ levels in $\mathrm{G}_{2}$ showed significant increase at one month after birth. Conclusion: $S C$ is a good feed additive for she-camels during peri-partum. It improved total body weight, body weight gain and birth weight of calves. Immune responses of dams and calves were enhanced that may help in facing the stressful pregnancy event.
\end{abstract}

Keywords: She-camel, Yeast, Immunity, Calf, Peri-parturation; Body weight, Parasitosis.

\section{Introduction}

Camelus dromedarius (One-humped camel) is one of the important domestic animals in arid and semi-arid regions, due to their superior capability to produce low cost and high quality meat and milk (Muzzachi et al, 2015). FAO (2013) Statistics had recorded that camel population in Egypt is 152,946 head that well worth to focus on its development in the area.

The pregnancy is one of the physiological stressors that might affect she-camel's performance especially during peri-parturient period thus it may adversely affect animal's immunity (Al-Zamely, 2011), damage its biological macromolecules and disruption of normal metabolism and physiology (AbdelAal and Eid, 2014). In camels, herd productive efficiency is also greatly influenced by the high mortality rate of camel calves in their first 3 months due to the harsh desert conditions and infectious diseases. Improving she-camel's health during peri-parturation were important for the health status of the newborn calves that come to life almost deprived of serum immunoglobulins (Igs) and depend on colostrum for virtually all humoral passive immunity (Silva et al, 2013).

Probiotics are one of those feed strategies that have been used for various livestock species to improve animal health and production (Vivek et al, 2014). They are known to be live micro-organisms which when administered in adequate amounts confer a health benefit to the host (FAO, 2009). Probiotics have been reported to improve growth performance, nutrient digestibility, balance of the intestinal microflora and importantly promote the immune function (Zhang and 
Kim, 2013). Live yeast, yeast cell wall or their extracts were used in ruminant feeding as a natural protein source to improve animal performance, health and immune responses (Burdick Sanchez et al, 2014).

The major components of yeast or its cell wall are polysaccharides such as $\alpha$ or $\beta$ glucans (Kogan and Kocher, 2007) that can be used as feed additives. They may interact directly with the immune cells or bind to pathogenic bacteria preventing attachment or colonization in Gastro-intestinal tract (Posada et al, 2014). Also, yeast cell wall has antioxidant compounds (Kogan et al, 2005).

Generally, this unique animal that inhabits arid areas in the world faces some health problems that need to be solved in order to maintain this great animal species from extinction. Hence, there were no applied researches that focus on improving camel production performance by using probiotics; this makes our work novel applied results. The aims of our work were to develop the production performance of camels by improving health of pregnant one by enhancing immunity during stressful event, increasing body weight, improving its milk's immunological value expected to have positive effects on health, birth weights and calves' immunity that form the unit of herd and milk immunological value.

\section{Materials and Methods}

Ethical Approval: All experiments were done in accordance with the ethical guidelines and regulations set forth by the Institutional Animal Care and Use Committee (IACUC) in Egypt.

Probiotic strain: Levucell (SC20), a commercial probiotic product of dried live yeast (Lallemand SAS Co.) was used. Composed ingredient of the live yeast was Saccharomyces cerevisiae (SC), $\left(20 \times 10^{9} \mathrm{CFU} / \mathrm{g}\right)$.

Table 1: Experimental durations at which

\begin{tabular}{|c|c|c|c|c|c|}
\hline Time from calving & $\begin{array}{c}\text { Dams' plasma } \\
\text { sampling }\end{array}$ & $\begin{array}{c}\text { Dams' body } \\
\text { weights }\end{array}$ & $\begin{array}{c}\text { Milk } \\
\text { Sampling }\end{array}$ & $\begin{array}{c}\text { Calves' plasma } \\
\text { sampling }\end{array}$ & $\begin{array}{c}\text { Calves' body } \\
\text { weights }\end{array}$ \\
\hline Two months pre-calving & $\sqrt{ }$ & $\sqrt{ }$ & - & - & - \\
\hline One month pre-calving & $\sqrt{ }$ & $\sqrt{ }$ & - & - & - \\
\hline At calving & $\sqrt{ }$ & $\sqrt{ }$ & $\sqrt{ }$ & $\sqrt{ }$ & - \\
\hline One week post calving & $\sqrt{ }$ & - & $\sqrt{ }$ & $\sqrt{ }$ & - \\
\hline One month post calving & $\sqrt{ }$ & $\sqrt{ }$ & $\sqrt{ }$ & $\sqrt{ }$ & - \\
\hline
\end{tabular}

Animal grouping and experimental durations: Ten healthy pregnant dromedary shecamels at their late gestation period (at $10^{\text {th }}$ month of pregnancy; two months pre-calving) with body weights ranged from 570 to $600 \mathrm{~kg}$ and housed at Camels Studies and Production Development Center (CSPDC), Matrouh Governorate, western northern of Egypt. All dams were fed basal diet starting at the transition period of pregnancy (at $10^{\mathrm{th}}$ month of pregnancy) and ended at one month post-calving. Dams were divided into two groups of five dams each: GI (Control): dams fed the basal diet only. GII: dams were fed the basal diet \& $0.5 \mathrm{gm}$ of $S C /$ head daily (included in a palm date to avoid loss after manufacturer's recommendations).

Laboratory examination: Urine to diagnose a urinary tract or kidney infections (Wilson and Anderson, 1993) and to exclude balantidiasis (Tajik et al, 2013). The stool analysis involved collection and analysis of fecal matter to diagnose the presence or absence of gastrointestinal parasites (El-Naggar et al, 2006), as eggs of Marshallagia spp. Nematodirus spp. Haemonchus spp. and Trichuris spp. Trichostrongyle spp. as well as oocysts of Eimeria cameli (Radfar and Gowhari, 2013). Blood was examined for parasite interferes with Igs levels (Morsy et al, 2001), as Babesia spp. Theilera spp. (el Kady, 1998) and Trypanosoma evansi (Haridy et al, 2011) and Toxoplasma gondii (Gebremedhin et al, 2014). Also, they were examined carefully for the ecto-parasites (el-Azazy, 1996), especially tick infestation as $\mathrm{Hya}$ lomma spp. (El Kammah et al, 2001) and the nasal nasal-botfly myiasis as Cephalopina titillator (Morsy et al, 1998). Body weights (Bwt) were recorded monthly. Plasma and milk samples were collected at certain durations as follows (Table 1). 
Blood Sampling and Plasma preparation: Blood samples were collected from the Jugular vein of dams and their calves into vacutainer tubes containing EDTA (an anticoagulant), centrifuged at $3000 \mathrm{rpm} / 10 \mathrm{~min}$ to obtain plasma which were kept at $-20^{\circ} \mathrm{C}$ until analysis.

Milk sampling and Whey preparation: Milk was collected in sterilized tubes and trans-formed into whey. Ten $\mathrm{ml}$ of milk or colostrum were centrifuged at $4000 \mathrm{rpm}$ at $4^{\circ} \mathrm{C}$ for 30 minutes to remove the floating fat drop then warmed in a water bath at $40-45^{\circ} \mathrm{C}$ for 30 minutes, after that some drops of freshly prepared Rennet solution were added and incubated in the water bath again. $\mathrm{Ca}$ sein clot aggregated with the remaining fat was filtered to obtain clear whey and stored at $-20^{\circ} \mathrm{C}$ until needed (Hyun et al, 2014).

Immuno-Assay: $\operatorname{IgG}, \operatorname{IgA}$ and the cytokine IFN- $\gamma$ were quantitatively detected by Sandwich ELISA (Aydin, 2015). Procedures were done according to the manufacturers' instructions (Camel IgG ELISA, Life Diagnostics Inc., Catalog No: IGG-16; Camel IgA ELISA, Mybiosource, Catalog Number: MBS073806 and Camel IFN- $\gamma$ ELISA, Wuhan Fine Biological Technology Co., Ltd., Catalog Number: ECM0009).

Table 2: Body weight of dams in experimental groups at different times from calving.

\begin{tabular}{|c|c|c|}
\hline Dams' Body Weight $(\mathrm{kg})$ & $\mathrm{G}_{1}($ Control $)$ & $\mathrm{G}_{2}$ (Yeast) \\
\hline At start of experiment & $579.67 \pm 3.18$ & $581.33 \pm 1.86$ \\
\hline One month after starting & $591.33 \pm 4.06^{\mathrm{B}}$ & $605 \pm 1.16^{\mathrm{A}}$ \\
\hline Post-partum & $553.33 \pm 3.28$ & $561.90 \pm 1.07$ \\
\hline One month post-partum & $563.67 \pm 3.53^{\mathrm{B}}$ & $578.9 \pm 0.86^{\mathrm{A}}$ \\
\hline
\end{tabular}

A, B (mean $\pm \mathrm{SE}$ ) within same row with different superscripts differ significantly $(\mathrm{P}<0.05)$ from each other. $\mathrm{G}_{1}$ : control group, $\mathrm{G}_{2}$ : group of animals fed Saccharomyces cervaiase.

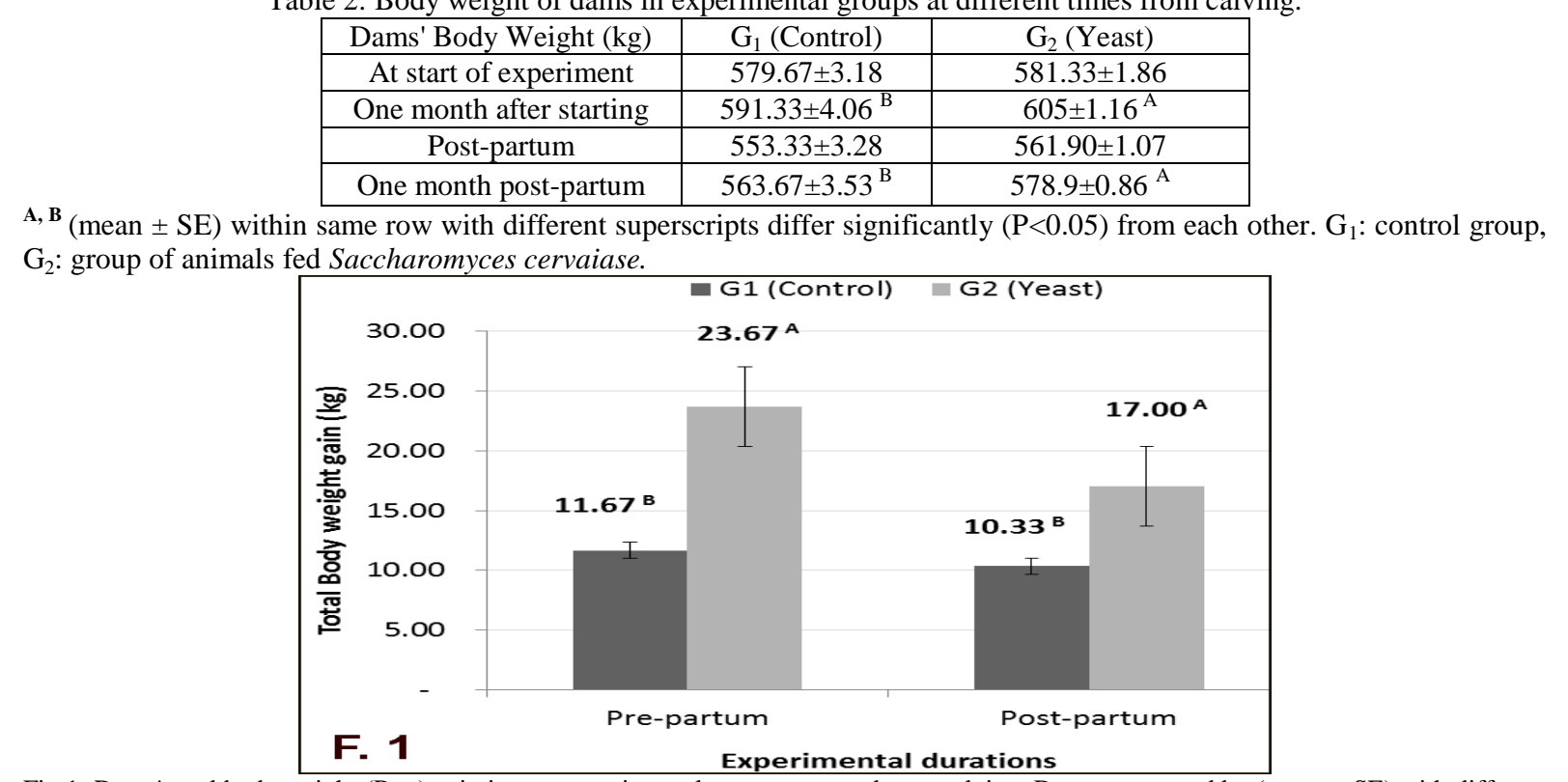

Fig 1: Dams' total body weight (Bwt) gain in two experimental groups pre- and post-calving. Data represented by (mean \pm SE) with different superscripts ${ }^{(A, B)}$ differ significantly $(\mathrm{P}<0.05)$ from each other. $\mathrm{G}_{1}$ : control group, $\mathrm{G}_{2}$ : dams fed Saccharomyces cervaiase
Statistical Analysis: Data are presented as means \pm Standard error (SE) of each group was calculated from mean values individually. Comparison between groups was done using T test. Analysis was carried out using SAS User's Guide: Statistics procedure of SAS version 9.1 for Windows (SAS, 2004).

\section{Results}

Effect of SC feed addition on she-camels' Bwt and its impact on their newborn calves' birth weight: Bwt of dams in the two experimental groups before SC addition were nearly similar. After one month, the Bwt of $\mathrm{G}_{2}$ dams were significantly higher when compared to $\mathrm{G}_{1}(605 \mathrm{~kg}$ vs. $591.33 \mathrm{~kg}$, res pectively). Bwt gains pre-calving were higher in $\mathrm{G}_{2}(23.67 \pm 0.88 \mathrm{~kg})$ compared to $\mathrm{G}_{1}$; $(11.67 \pm 0.88 \mathrm{~kg})$. But, there was non-significant difference in Bwt of dams in the two experimental groups directly after delivery; however $G_{2}$ was numerically higher than $G_{1}$. Dams' Bwt in $\mathrm{G}_{2}$ was significantly higher $(578.9 \mathrm{~kg})$ than $\mathrm{G}_{1}(563.67 \mathrm{~kg})$ one month post-calving. Bwt gained post-calving was high in $\mathrm{G}_{2}(17 \pm 1 \mathrm{~kg}$,$) than \mathrm{G}_{1}(10.33 \pm 0.33$ $\mathrm{kg}$ ).

Details are given in tables $(2,3,4 \& 5)$ and figures $(1,2 \& 3)$. 


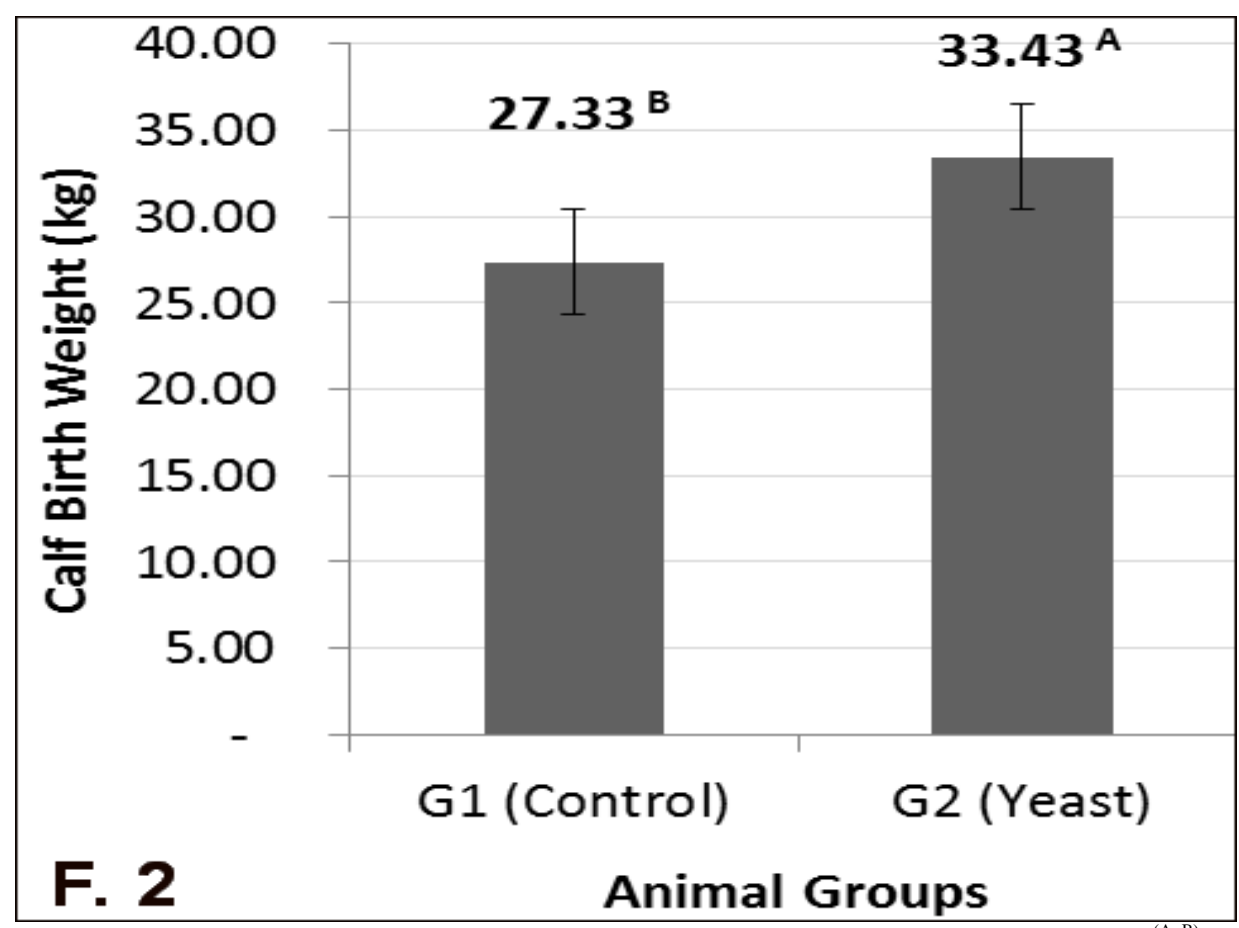

Fig 2: Calves' birth weight in the experimental groups. Data represented by (mean \pm SE) with different superscripts ${ }^{(\mathrm{A}, \mathrm{B})}$ differ significantly $(\mathrm{P}<0.05)$ from each other. $\mathrm{G}_{1}$ : calves of control dams, $\mathrm{G}_{2}$ : calves of dams fed Saccharomyces cervaiase.

Calves' birth weights showed significant differences between experimental groups, calves birth weights in $G_{2}$ dams were higher $(33.43 \pm 0.69 \mathrm{~kg})$ than in $\mathrm{G}_{1}(27.33 \pm 0.88 \mathrm{~kg})$

Table 3: Concentrations of IgG, IgA and IFN- $\gamma(\mathrm{ng} / \mathrm{ml})$ in she-camels' plasma of experiments at different times from calving

\begin{tabular}{|c|c|c|c|}
\hline \multirow{3}{*}{ Time from calving } & \multirow{3}{*}{ Parameter } & \multicolumn{2}{|c|}{ Animal groups } \\
\hline & & $\mathrm{G}_{1}$ (Control) & $\mathrm{G}_{1}$ (Control) \\
\hline & & Mean \pm SE & Mean \pm SE \\
\hline \multirow{3}{*}{ Two months pre-calving } & $\operatorname{IgG}$ & $1.61 \pm 0.18$ & $2.92 \pm 0.74$ \\
\hline & $\operatorname{IgA}$ & $3.34 \pm 0.34^{\mathrm{A}}$ & $2.14 \pm 0.37^{\mathrm{B}}$ \\
\hline & IFN- $\gamma$ & $0.01 \pm 0.001$ & $0.01 \pm 0.006$ \\
\hline \multirow{3}{*}{ One month pre-calving } & $\mathrm{IgG}$ & $2.45 \pm 0.22^{\mathrm{B}}$ & $4.73 \pm 0.04^{\mathrm{A}}$ \\
\hline & $\operatorname{Ig} \mathrm{A}$ & $2.94 \pm 0.27$ & $2.29 \pm 0.39$ \\
\hline & IFN- $\gamma$ & $0.02 \pm 0.003$ & $0.02 \pm 0.002$ \\
\hline \multirow{3}{*}{ At calving } & $\mathrm{IgG}$ & $3.38 \pm 0.42^{\mathrm{B}}$ & $4.31 \pm 0.09^{\mathrm{A}}$ \\
\hline & $\operatorname{Ig} \mathrm{A}$ & $2.81 \pm 0.11$ & $3.20 \pm 0.46$ \\
\hline & IFN- $\gamma$ & $0.03 \pm 0.001^{\mathrm{B}}$ & $0.04 \pm 0.002^{\mathrm{A}}$ \\
\hline \multirow{3}{*}{ One week post-calving } & $\mathrm{IgG}$ & $3.75 \pm 0.41^{\mathrm{B}}$ & $5.44 \pm 0.63^{A}$ \\
\hline & $\operatorname{Ig} \mathrm{A}$ & $2.33 \pm 0.08$ & $2.44 \pm 0.28$ \\
\hline & IFN- $\gamma$ & $0.04 \pm 0.001^{\mathrm{B}}$ & $0.07 \pm 0.004^{\mathrm{A}}$ \\
\hline \multirow{3}{*}{ One month post-calving } & $\mathrm{IgG}$ & $2.25 \pm 0.36^{\mathrm{B}}$ & $4.07 \pm 0.54^{\mathrm{A}}$ \\
\hline & IgA & $2.14 \pm 0.09$ & $2.08 \pm 0.11$ \\
\hline & IFN- $\gamma$ & $0.03 \pm 0.001^{B}$ & $0.05 \pm 0.002^{\mathrm{A}}$ \\
\hline
\end{tabular}

A, B $\left(\right.$ mean \pm SE) within same row with different superscripts differ significantly $(\mathrm{P}<0.05)$ from each other. $\mathrm{G}_{1}$ : control group, $\mathrm{G}_{2}$ : dams fed Saccharomyces cerevisiae.

Effect of SC feed addition on $\operatorname{IgG}, \operatorname{Ig} \mathrm{A}$ and IFN- $\gamma$ levels in she-camels' plasma during peri-parturation: At one month before the expected calving date (after one month of $S C$ addition), IgG; the most important Ig in camels, showed a significant increase $(\mathrm{P}<0.05)$ in $\mathrm{G}_{2}(4.73 \mathrm{ng} / \mathrm{ml})$ compared to $\mathrm{G}_{1}$ $(2.45 \mathrm{ng} / \mathrm{ml})$. Neither the concentration of IgA nor the concentration of IFN- $\gamma$ showed any significant changes between the experimental groups. At calving, the concentration of IgG and IFN- $\gamma$ showed significant increases $(P<0.05)$ in $\mathrm{G}_{2}$ compared to $\mathrm{G}_{1}$ while IgA concentration did not show any change in the two groups (Table 3). At one week post-calving, IgG concentrations in $\mathrm{G}_{2}$ began to increase again when compared to $G_{1}$, while IgA concentrations didn't show any 
significant differences between the two groups. The levels of IFN- $\gamma$ continued to show high and peak levels in $\mathrm{G}_{2}(0.07$ $\mathrm{ng} / \mathrm{ml})$ compared to $\mathrm{G}_{1}(0.04 \mathrm{ng} / \mathrm{ml})$. At one month post-calving, IgG and IFN- $\gamma$ levels decreased but continued to maintain higher levels in $G_{2}$ more than $G_{1}$ but IgA was still showing no change at all.

Table 4: Comparison between the concentrations of $\operatorname{IgG}, \operatorname{IgA}$ and IFN- $\gamma(\mathrm{ng} / \mathrm{ml})$ detected in milk of she-camels in experimental groups.

\begin{tabular}{|c|c|c|c|}
\hline \multirow{3}{*}{ Time from calving } & \multirow{3}{*}{ Parameter } & \multicolumn{2}{|c|}{ Groups } \\
\hline & & G1 & G2 \\
\hline & & Mean \pm SE & Mean \pm SE \\
\hline \multirow{3}{*}{ At calving } & $\lg G$ & $1.46 \pm 0.03$ & $1.24 \pm 0.09$ \\
\hline & $\lg A$ & $2.04 \pm 0.51$ & $2.75 \pm 0.15$ \\
\hline & IFN- $\gamma$ & $0.01 \pm 002$ & $0.02 \pm 0.004$ \\
\hline \multirow{3}{*}{ One week post-calving } & $\lg G$ & $1.32 \pm 0.14$ & $2.28 \pm 0.35$ \\
\hline & $\lg A$ & $1.74 \pm 0.15$ & $2.37 \pm 0.15$ \\
\hline & IFN- $\nu$ & $0.02 \pm 0.003$ & $0.03 \pm 0.010$ \\
\hline \multirow{3}{*}{ One month post- calving } & $\lg G$ & $1.69 \pm 0.08$ & $2.24 \pm 0.54$ \\
\hline & $\lg A$ & $2.11 \pm 0.40$ & $1.84 \pm 0.06$ \\
\hline & IFN- $\gamma$ & $0.03 \pm 0.009$ & $0.04 \pm 0.010$ \\
\hline
\end{tabular}

Note: no statistical differences were detected between different groups concerning $(\mathrm{P}>0.05)$ in the concentrations of $\operatorname{IgG}, \operatorname{IgA}$ or IFN- $\gamma$ passively transferred into milk of dams of the two groups. $\mathrm{G}_{1}$ : control group, $\mathrm{G}_{2}$ : dams fed Saccharomyces cervaiase.

Effect of SC feed addition on IgG, IgA and IFN- $\gamma$ levels in she-camels' milk: IgG levels showed non-significant difference between $\mathrm{G}_{1}$ and $\mathrm{G}_{2}$ at all but was found to be numerically higher in $\mathrm{G}_{2}$ compared to $\mathrm{G}_{1}$ at one week post-calving and one month postcalving $\mathrm{ng} / \mathrm{ml}$ respectively. IgA levels also revealed non-significant differences between groups while the numerical values showed that $G_{2}$ had higher values compared to $G_{1}$ at calving until at one week post-calving respectively. For the concentration of IFN- $\gamma$, there was no significant difference between groups at all the studied periods but there were numerically higher in $G_{2}$ more than $G_{1}$ at all durations.

Table 5: Concentrations of IgG, IgA \& IFN- $\gamma(\mathrm{ng} / \mathrm{ml})$ in plasma of calves born to dams of experimental groups during lactation.

\begin{tabular}{|c|c|c|c|}
\hline \multirow{3}{*}{ Time from birth } & \multirow{3}{*}{ Parameter } & \multicolumn{2}{|c|}{ Animal groups } \\
\hline & & $\mathrm{G}_{1}$ (Control) & $\mathrm{G}_{1}$ (Control) \\
\hline & & Mean \pm SE & Mean \pm SE \\
\hline \multirow{3}{*}{ At birth } & IgG & $2.21 \pm 0.91^{\mathrm{B}}$ & $4.26 \pm 0.19^{\mathrm{A}}$ \\
\hline & $\operatorname{IgA}$ & $1.99 \pm 0.43$ & $1.61 \pm 0.50$ \\
\hline & IFN- $\gamma$ & $0.01 \pm 0.002$ & $0.01 \pm 0.002$ \\
\hline \multirow{3}{*}{ One week after birth } & $\mathrm{IgG}$ & $2.59 \pm 0.71^{\mathrm{B}}$ & $4.95 \pm 0.30^{\mathrm{A}}$ \\
\hline & IgA & $1.69 \pm 0.34$ & $2.03 \pm 0.41$ \\
\hline & IFN- $\gamma$ & $0.02 \pm 0.002$ & $0.03 \pm 0.010$ \\
\hline \multirow{3}{*}{ One month after birth } & $\mathrm{IgG}$ & $2.03 \pm 0.48^{B}$ & $4.99 \pm 0.19^{\mathrm{A}}$ \\
\hline & $\operatorname{IgA}$ & $3.01 \pm 0.38^{\mathrm{B}}$ & $5.41 \pm 1.10^{\mathrm{A}}$ \\
\hline & IFN- $\gamma$ & $0.02 \pm 0.003^{\mathrm{B}}$ & $0.04 \quad 0.004^{\mathrm{A}}$ \\
\hline
\end{tabular}

${ }^{A, B}$ (mean $\pm S E$ ) within the same row with different superscripts differ significantly $(P<0.05)$ from each other. $G_{1}$ : calves of control dams, $\mathrm{G}_{2}$ : calves of dams fed Saccharomyces cervaiase.

Impact of SC feed addition to she-camels on the immune responses (IgG, IgA \& IFN$\gamma$ ) of the newborn calves: Plasma IgG, IgA $\&$ IFN- $\gamma$ levels in calves of experimental groups from birth to one month after birth. Significant differences $(\mathrm{P}<0.05)$ between the two experimental groups in concentrations of $\operatorname{IgG}$ were shown, where calves born to $\mathrm{G}_{2}$ dams had higher IgG levels than calves born to $\mathrm{G}_{1}$ dams at all durations. Besides, at birth the IgA \& IFN- $\gamma$ levels in calves' plasma didn't show any significant differences between the experimental groups. At one week after birth, IgA \& IFN- $\gamma$ levels didn't differ significantly between two experimental groups. At one month after birth, both $\operatorname{IgA} \&$ IFN- $\gamma$ levels in $G_{2}$ were significantly higher as compared to $\mathrm{G}_{1}$. 


\section{Discussion}

The present results showed that oral administration of $S C$ gave positive effects on dams' Bwt after one month of administration pre-calving. Dams' Bwts were higher in treated animals than control at calving and one month post-calving. $S C$ administration had improved dam's daily Bwt gain pre/postcalving. The results agreed with Casey et al. (2007) who tested some probiotics separately or in combination on growth performance of sheep, goat and cattle. Improvement of growth performance may be related to feed higher consumption, microbial ecology improvement of the animal and nutrients absorption resulting in better weight gain $(\mathrm{Mu}-$ sa et al, 2009). Yeast and their products strongly enhanced animal performance and increased body weight in beef cattle (Finck et al, 2014).

The present results showed that birth weights of calves related to dams administered $S C$ were higher than control group. $S C$ administration enhanced nutrient transfer from dams to the newborn during pregnancy, thus was expected to have a positive impact on birth of newborns and general health status. This result agreed with Shen et al. (2011) who found that yeast administration to sows during gestation increased piglets weaning weight and average daily gain.

The effect of adding $S C$ to feed affected some immune responses of late pregnant she-camels and during early lactation period. Levels of IgG, IgA or cytokine IFN- $\gamma$ in plasma of dams were positively influenced by yeast against exposure to various stress events (pregnancy, delivery or lactation). For IgG levels in plasma of dams, $S C$ addition had positive effects on $\mathrm{G}_{2}$ compared to $\mathrm{G}_{1}$. This effect appeared after one month after oral administration and continued at calving, peak levels at one week postcalving and decreased slightly at one month post-calving. Plasma IgA levels in $\mathrm{G}_{2}$ dams increased slightly at calving. This result agreed with Cakiroglu et al. (2010) who reported that $S C$ feed supplementation acted as an immune-stimulant when given daily to dairy cows. Yin et al. (2008) found that galactomannan-oligo-saccharides (a yeast product) feed supplementation, enhanced serum levels of Igs.

The present results of addition $S C$ to diet of late pregnant she-camels had positive effects on the pro-inflammatory IFN- $\gamma$ levels by the time calving, continued greatly to one week after calving and one month after calving. This result agreed with Collier et al. (2011) who found that yeast elicited inflammatory immune responses and reduced pigs' mortality. $S C$ cell wall as an immunemodulators interacted directly or indirectly with pathogens and the organism's immune system, and stimulated synthesis and release of pro-inflammatory cytokines from macrophages, neutrophils or T lymphocytes in the swine (Xiao et al, 2004).

Mammalian milk is known to be enrich-ed with Igs to give passive immune protection against antigens and micro-organisms in the GIT of mother or environmental antigens coming in contact. The Igs are present at the highest concentrations in the first few days post-partum (colostrum) and then falls progressively (Kleinman and Walker, 1997).

The present results showed that the effect of oral administration of $S C$ dams on $\mathrm{IgG}$ levels in the milk possess similar trends such as the plasma IgG levels. The treated group showed variable higher milk IgG levels than the untreated ones during supplying colostrum. IgG levels in milk of dams administered $S C$ showed a peak one week and one month post-calving. In dams' milk fed $S C$, IgA levels didn't show significant changes but, IFN- $\gamma$ levels released in milk were higher in dams given $S C$ more than untreated dams starting from calving, continued to one week post-calving up to one month postcalving.

The presence of immunological factors in milk illustrated where B \& $\mathrm{T}$ cells induced by an antigen such as SC, were able to migrate via different lymphatics and via the mesenteric nodes reached the systemic cir- 
culation through the thoracic duct and repopulated in mammary glands hence the assumption of an increased IgG production in milk of dams. This fact agreed with the phenomenon "Common Mucosal System" (Cebra et al, 1991). She-camel, unlike other ruminants' females, has an impermeable epitheliochorial placenta, which prevented intra-uterine passage of antibodies and other immunological factors from dam to fetus during pregnancy (Moffett and Loke, 2006). This impermeability is related to the unique structure of six layers of cells between maternal and fetal circulations (maternal capillary endothelium, uterine connective tissue, uterine epithelium, chorionic epithelium, fetal connective tissue and fetal capillary endothelium); so the calves were born with the hypogammaglobulinemia and immature immunity (Enders and Carter 2004). So, the maternal protection to fetus during pregnancy postponed calf specific immunity (Silva et al., 2013). Also, the innate immune system of the fetus or newborn calves was immunosuppressed due to maternal hormones released during late pregnancy (Benesi et al, 2012).

Colostrum is the only source for immune protection which ensures the survival of calves in their first months of life via the natural passive transfer of the majority of immune factors such as Igs and cytokines from dams to them (Silva et al, 2013). During early lactation, Igs in colostrum are absorbed via unselective permeability of epithelial cells in calf's small intestine then are transported through intestinal lymphatic tissue to reach its circulatory system (Riddle, 2003). The pro-inflammatory cytokines such as IFN- $\gamma$ are also present in maternal colostrum and possibly absorbed by the intestinal mucosa of calves, reaching the highest concentrations in newborn bloodstream at the first 72 hours of their life (Madureira, 2011). But, a calf might have IFN- $\gamma$ levels prior to colostrum intake, probably due to antigen contact during pregnancy where some microorganisms could cross the placenta and innate immune system of calves was then the main defense during pregnancy (Gomes et al, 2014).

Knowledge of passive transfer of immunity to young calves led to focus on improving the immune factors in pregnant dams by the probiotics usage as immuno-stimulators.

The presented study also showed that plasma $\mathrm{IgG}$ levels in calves (related to $\mathrm{G}_{2}$ dams) were greatly enhanced compared to the untreated counterparts from birth (during colostrum suckling), to one week after birth and up one month after birth (during milk suckling). Also, plasma IgA levels in calves (related to dams fed SC) were higher than calves related to untreated dams at one week after birth and reached the peak levels one month after birth. The plasma IFN- $\gamma$ levels in calves (dams fed $S C$ ) were higher in levels starting from one week after birth and continued up to one month after birth but also calves were born with plasma containing IFN- $\gamma$. This agreed with Gomes et al., (2014) who reported the probability of microorganism passage via the placenta and potentiating the innate immune system of fetus during pregnancy.

The addition of yeast to diets of dairy cattle enhanced performance of the newborn calves and decreased morbidity and mortality (Magalhaes et al, 2008). Also, when gestating sows were supplemented with $S C$, an improvement of newborns health was achieved (Shen et al, 2011).

The mode of action by which yeast or their products affect immunity and health of an animal may be one of the following postulations. It must be known that yeast composing polysaccharides are indigestible by the digestive system's enzymes in mammals and are supposed to reach the large intestine where they may be fermented by commensal microbiota that in turn caused changes into the bacterial composition and the released metabolic compound (de verse et al, 2008). The yeast also alter with the microbiome in the GIT of a ruminant and promote beneficial bacteria; thus aid in development of the 
healthy intestinal flora enhancing nutrient uptake and improving immune function (Mullins et al, 2013). Live yeast cell wall polysaccharides directly bound to pathogenic bacteria and inhibited their bin-ding and colonization in the GIT (Posada et al, 2014).

A third postulation suggested that some yeast cell wall components as mannons and $\beta$-glucans might have direct effects on leukocytes and secretions of pro-inflamma-tory cytokines through the intestinal mucosal epithelium to play a major role in orga-nizing gut immune system. Intraepithelial lymphocytes and dendritic cells (DC) protruded their dendrites through the epithelial lining and became in contact with gut lumen, thus, direct interaction with $\beta$-glucans occurs (Qi et al, 2011) and transporting them to gastrointestinal lymph nodes to the circulating blood to the bone marrow, lymph nodes and spleen (Sandvik et al, 2007). Yeast cell wall compounds was taken up by specialized epithelial cells; Mast cells in lymphoid follicles associated within Peyer's patches (Volman et al, 2008).

\section{Conclusion}

The outcome results showed that the inclusion of Saccharomyces cerevisiae as feed additive to regular diets of pregnant dromedary she-camels is effective for improvement of their body weights at the periparturition period, for enhancement of immune responses of them during stressful events and positively reflects on birth weight and health of their newborn calves.

Therefore, it is recommended to add Yeast in the regular diet of pregnant she-camels in order to recover their health and in turn the newborns' health. This systemic chain improved teconomic value of this great animal.

\section{Acknowledgement}

The authors would like to thank Dr. Mohamed A. Salama, Professor of Animal breeding and Dr. Reda E. Hamouda, Assistant Researcher at Animal Production Systems Department, Animal Production Research Insti- tute (APRI) for their kind help in the statistical analysis.

Thanks are extended to all the colleagues.

\section{References}

Abdel-Aal ES, Eid, LN, 2014: Influence of probiotic supplementation on oxidative stress and performance of she-camel during the transition period. Egypt. J. Basic Appl. Physiol. 14, 2:255-70.

Al-Zamely, H, 2011: Oxidant-anti-oxidant status and some biochemical parameters in pregnant and non-pregnant Iraqi she-camels. Iraqi J. Vet. Med. 35, 2:46-51.

Aydin, S, 2015: A short history, principles, and types of ELISA, and our laboratory experience with peptide/protein analyses using ELISA. Peptides 72:4-15.

Benesi, J, Teixeira, CMC, Leal, MLR, Lisboa, JAN, Mirandola, RMS. 2012: Leukograms of healthy Holstein calves within the first month of life. Pesquisa Vet. Brasil. 32:352-6.

Burdick Sanchez, NC, Young, TR, Carroll, JA, Corley, JR, Rathmann, RJ, et al, 2014: Yeast cell wall supplementation alters the metabolic responses of crossbred heifers to an endotoxin challenge. Innate Immun. 20:104-12.

Cakiroglu, D, Meral, Y, Pekmezci, D, Onuk, EE, Kabak, YB, 2010: Effects of yeast culture (Saccharomyces cerevisiae) on humoral and cellular immunity of Jersey Cows in early lactation. J. Anim. Vet. Adva. 9:1534-8.

Casey, PG, Gardiner, GE, Casey, G, Bradshaw, B, Lawlor, PG, et al, 2007: A five-strain probiotic combination reduces pathogen shedding and alleviates disease signs in pigs challenged with Salmonella enteric Serovar typhimurium. Appl. Environ. Microbiol. 73:1858-63.

Cebra, J, Schrader, C, Shoroff, K, Weinstein, P, 1991: Are Peyer's patch germinal Centre reactions different from those occurring in other lymphoid tissues? Res. Immunol. 142:222-6.

Collier, CT., Carroll, JA, Ballou, MA, Starkey, JD, Sparks, JC, 2011: Oral Administration of Saccharomyces cerevisiae boulardi reduces mortality associated with immune and cortisol responses to Escherichia coli endotoxin in Pigs. J. Anim. Sci. 89:52-8.

de Vrese, M, Schrezenmeir, J, 2008: In: Stahl, U, Donalies, UEB, Nevoigt, E, (Eds.): Food Biotechnology, Springer-Verlag Berlin. 
Enders, AC, Carter, AM, 2004: What can comparative studies of placental structure tell us? A review. A. Trophoblast. Res. 18:S3-9.

el-Azazy, OM, 1996: Camel tick (Acari: Ixodidae) control with pour-on application of flumethrin. Vet. Parasitol. 67, 3/4:281-4.

El-Naggar, SM, El-Bahy, MM, Abd Elaziz, J, El-Dardiry, MA, 2006: Detection of protozoal parasites in the stools of diarrhoeic patients using different techniques. J. Egypt. Soc. Parasitol. $36,1: 7-22$.

el Kady, GA, 1998: Protozoal parasites in tick species infesting camels in Sinai Peninsula. J. Egypt. Soc. Parasitol. 28, 3:765-76.

El Kammah, KM, Oyoun, LM, El Kady, GA, Shafy, SA, 2001: Investigation of blood parasites in livestock infested with argasid and ixodid ticks in Egypt. J. Egypt. Soc. Parasitol. 31, 2:365-71.

FAO, 2009: Food and Agriculture Organization of the United Nations: Guidelines for the evaluation of probiotics in food. ftp://ftp.fao. org/es/ esn/food/wgreport2.

FAO, 2013: Statistics: The camel Population in Egypt.

Finck, D, Ribeiro, F, Burdick, N, Parr, S, Carroll, J, et al, 2014: Yeast supplementation alters the performance and health status of receiving cattle. Prof. Anim. Sci. 30:333-41.

Gebremedhin, EZ, Yunus, HA, Tesfamaryam, G, Tessema, TS, Dawo, F, et al, 2014: First report of Toxoplasma gondii in camels ( $\mathrm{Ca}$ melus dromedarius) in Ethiopia: bioassay and seroepidemiological investigation. BMC Vet. Res. 10:222-7.

Gomes, V, Baccili, CC, Baldacim, VAP, Madureira, KM, Guilloux, AGA, et al, 2014: Development of the innate immune response and influence of colostrum suckling in calves. American J. Anim. Vet. Sci. 9, 2:77-83.

Haridy, FM, El-Metwally, MT, Khalil, HH, Morsy, TA, 2011: Trypanosoma evansi in dromedary camel: with a case report of zoonosis in greater Cairo, Egypt. J. Egypt. Soc. Parasitol. 41, 1:65-76.

Hyun, J, Won Hae, C, Yi Hana, J, Hyunnho, $\mathrm{C}$, Bomee, L, et al, 2014: Whey preparation methods \& thermal treatments of milk affect recovery of lactoferrin using ion-exchange chromatography. J. Food Process. Preserv. 39: 1976-82.

Kleinman, PE, Walker, WA. 1997: The enteromammary immune system: an important new concept in breast milk host defense. Dig. Dis. Sci. 24:876-82.

Kogan, G, Kocher, A, 2007: Role of yeast cell wall polysaccharides in pig nutrition and health protection. Livestock Sci. 109, 1/3:161-5.

Magalhães, V, Susca, F, Lima, F, Branco, A, Yoon, I, et al, 2008: Effect of feeding yeast culture on performance, health, and immunocompetence of dairy calves. J. Dairy Sci. 91: 1497-509. Moffett, A, Loke, C, 2006: Immunology of placentation in Eutherian Mammals Nature 6: 584-94.

Morsy, TA, Aziz, AS, Mazyad, SA, al Sharif, KO, 1998: Myiasis caused by Cephalopina titillator (Clark) in slaughtered camels in Al Arish Abattoir, North Sinai governorate, Egypt. J. Egypt. Soc. Parasitol. 28, 1:67-73.

Morsy, TA, El Bahrawy, AF, El Dakhil, MA, 2001: Ecto- and blood parasites affecting Meriones rex trapped in Najran, Saudi Arabia. J. Egypt. Soc. Parasitol. 31, 2:399-405.

Mullins, C, Mamedova, L, Carpenter, A, Ying, Y, Allen, M, et al, 2013: Analysis of rumen microbial populations in lactating dairy cattle fed diets varying in carbohydrate profiles and Saccharomyces cerevisiae fermentation product. J. Dairy Sci. 96:5872-81.

Musa, HH, We, SL, Zhu, CH, Seri, HI, Zhu G Q, 2009: The potential benefits of probiotics in animal production \& health. J. Anim. Vet. Adv. 8:313-21.

Posadas, G, Carroll, JA, Corley, JR, Lawrence, A, Donaldson, JR, 2014: Yeast probiotics vary in their potential to bind to gram positive or gram negative bacteria. Proc. ADSA-ASASCSAS Joint Ann. Meet.Kansas City, MO, USA. Qi, C, Cai, Y, Gunn, L, Ding, C, Li, B, et al, 2011: Differential pathways regulating innate and adaptive antitumor immune responses by particulate \& soluble yeast-derived $\beta$-glucans. Blood 117:6825-36.

Radfar, MH, Gowhari, MA, 2013: Common gastrointestinal parasites of indigenous camels (Camelus dromedarius) with traditional husbandry management (free-ranging system) in central deserts of Iran. J. Parasit. Dis. 37, 2:225-30.

Riddle, WT. 2003: Preparation of the mare for normal parturition. Proceed. $49^{\text {th }}$ Ann. Convent. American Association of Equine Practitioners, AAEP, New Orleans.

Sandvik, A, Wang, YY, Morton, HC, Aasen, AO, et al. 2007: Oral and systemic administration of $\beta$-glucan protects against lipopolysaccha- 
ride-induced shock and organ injury in rats. Clin. Exp. Immunol. 148:168-77.

SAS, 2004: SAS user's guide: Statistics. Version 9.1. SAS Institute Inc., Cary, NC, USA.

Shen, Y, Carroll, J, Yoon, I, Mateo, R, Kim, S, 2011: Effects of supplementing fermentation product in sow diets on performance of sows and nursing piglets. J. Anim. Sci. 89: 2462-71.

Silva, NA, Honorio, AC, Giachini, FR, Mores, L, Souza, EGD, 2013: Bioactive factors of colostrum and human milk exhibits a day/night variation. Am. J. Immunol. 9:68-74.

Tajik, J, Fard, SRM, Paidar, A, Anousheh, S, Dehghani, E, 2013: Balantidiasis in a dromedarian camel. Asian Pac. J. Trop. Dis. 3, 5:409-12.

Vivek, KB, 2014: Use of encapsulated probiotics in dairy based foods. Int. J. Food, Agric. Vet. Sci. 3, 1:188-99.

Volman, JJ, Ramakers, JD, Plat, J, 2008: Dietary modulation of immune function by $\beta$ glucans. Physiol. Behav. 94:276-84.
Wilson, DM, Anderson, RL, 1993: Proteinosmolality ratio for the quantitative assessment of proteinuria from a random urinalysis sample. Am. J. Clin. Pathol. 100, 4:419-24.

Xiao, Z, Trincado, CA, Murtaugh, MP, 2004: $\beta$-glucan enhancement of T-cell IFN- $\gamma$ response in swine. Vet. Immunol. Immunopathol. 102: 315-320.

Yin, YL, Tang, ZR, Sun, ZH, Liu, ZQ, Li. T J, 2008: Effect of galactomannan oligosaccharides or chitosan supplementation on cytoimmunity and humoral immunity in earlyweaned piglets. AJAS. 21, 5:723-31.

Zhang, ZF, Cho, JH, Kim, IH, 2013: Effects of Bacillus subtilis UBT-MO2 on growth performance, relative immune organ weight, gas concentration in excreta, and intestinal microbial shedding in broiler chickens. Livestock Sci. 155:343-7. 